years, show that those whose interest in lilies is practical and aesthetic, need, and desire, the specialized help of the geneticist, the physiologist and the pathologist.

\section{Scientia Genetica}

WIтн the object of stimulating the development of genetics in the Latin countries, a new journal, Scientia Genetica, is being launched under the direction of Prof. Carlo Jucci of the University of Pavia and with his colleague Prof. Adriano BuzzatiTraverso as its editor-in-chief. Though it is primarily intended to provide an appropriate medium for publication for geneticists in these particular countries, original papers from elsewhere will be welcomed so long as they are written in Italian, French, Spanish or Portuguese, and possess a strictly genetical interest. There is to be a special section for abstracts, reviews of recent books and for summaries of original papers dealing with animal and plant breeding (such papers will not be published in full). At the end of each year there will be given a complete bibliography of papers of genetical interest that have appeared in the scientific literature of the Latin countries, and from time to time there will be presented a critical review of some selected field. Geneticists will welcome this addition to the literature of their science. It undoubtedly supplies a need, and it may be expected to play a notable part in the inevitable advancement of genetics not only in the Latin countries but also in the world as a whole.

\section{Beneficial Insects}

IN 1922 the Ministry of Agriculture and Fisheries issued a small publication on "Beneficial Insects". It contained little-known information, written in a non-technical style, on those insects that are beneficial to the farmer, fruit-grower and gardener. During the sixteen years which have elapsed, this bulletin has passed through three editions and has been reprinted on five occasions. Knowledge of insects of this kind has greatly increased in the interval and the practical measures that can be taken to increase their usefulness have been extensively investigated. This new bulletin (No. 20 ; 1939) has been entirely re-written by Dr. W. R. Thompson and forms a useful nontechnical introduction to the subject. It is obtainable from His Majesty's Stationery Office, or through any bookseller, price $9 d$. net.

\section{Advanced Study at the University of Cambridge}

The University of Cambridge has recently published abstracts of ninety-one dissertations approved during the academic year 1937-38 for the Ph.D. (75), M.Sc. (11) and M.Litt (5) degrees. The abstracts are full enough (averaging about a page and a half) to give a fair idea of the substance of the dissertations. They may be roughly grouped as follows: the humanities 26, pure science 55, applied science 10 . The actual distribution according to faculties is : divinity 2, moral science 2, classics 3, English 4, modern and medieval languages 6, history 3, economics and politics 3, archæology and anthropo- logy 2, geography 1 , mineralogy and petrology 4, mathematics 8 , physics 6 , chemistry 14 , botany and zoology 15, biochemistry and physiology 8, agriculture 3, engineering 7 .

\section{North Pacific Earthquake}

AN earthquake of moderate intensity occurred on November 17, 1938, and its epicentre has been determined by the United States Coast and Geodetic Survey in co-operation with Science Service and the Jesuit Seismological Association as lat. $55^{\circ} \mathrm{N}$., long. $158^{\circ} \mathrm{W}$. It is estimated to have normal focal depth. This preliminary determination was made with the help of readings from the following stations : Georgetown, Fordham, Weston, Chicago, Ann Arbor, Ukiah, Victoria, San Juan, St. Louis, Tueson, Philadelphia, Williamstown, Butte, Bozeman, Honolulu, Manila, Sitka, Pasadena, College, Burlington, Huancayo and Kew. The epicentre is situated under the ocean bed to the south of the Alaska Peninsula, and is not far distant from the scene of the violent earthquake of November 10 , which was lat. $56^{\circ} \mathrm{N}$., long. $150^{\circ} \mathrm{W}$.

\section{National Physical Laboratory: Publications}

THE demand for the first issue of the "National Physical Laboratory Abstracts", which covered papers contributed by the Laboratory to the scientific and technical press during the year 1936, has proved its value to industry and has justified the recent issue of a similar pamphlet for the year 1937. The abstracts of papers in the present issue cover sixty-seven pages and on the average an abstract occupies a little less than half a page. They are arranged in order of subject: engineering, metallurgy, electricity and heat and general physics abstracts occupying 7-11 pages each and other subjects less. Both author and subject indexes are provided. The pamphlet may be purchased directly from H.M. Stationery Office, price $1 s$.

\section{Finney-Howell Research Fellowships}

Finney-Howell Research Fellowships have been renewed for the following: Dr. P. C. Aebersold, University of California, Berkeley; Margaret E. Boyland, Royal Cancer Hospital, London; Dr. Alma Howard, McGill University, Montreal ; Dr. Ll. M. Joshel, Harvard University; Dr. Ll. W. Law, Jackson Laboratory for Cancer Research, Bar Harbor, Maine; Dr. H. Lisco, Johns Hopkins Hospital, Baltimore; Dr. C. S. MeEuen, MeGill University; Dr. W. C. Merkel, Union Memorial Hospital, Baltimore. Fellowships for 1939 have been awarded to the following: G. M. Badger, of Melbourne, Australia, to work at the Royal Cancer Hospital, London; Dr. A. Kirschbaum, to work at Yale University; Dr. J. L. Melnick, to work at Yale University; Dr. J. F. Menke, to work at Stanford University Hospital ; Dr. J. L. Wood, to work at Harvard University; Dr. P. C. Zamecnik, to work under Dr. K. Linderström-Lang at the Carlsberg Laboratory, Copenhagen. Grants in aid have been awarded to Dr. R. D. Fowler and Dr. R. W. 
Graham, jun., Johns Hopkins University, and Dr. G. O. Gey, Johns Hopkins Medical School. Applications for 1940 awards must reach the office of the Foundation (Medical and Chirurgical Faculty Building, 1211 Cathedral Street, Baltimore) by January 1, 1940.

\section{A Large Sunspot}

A LARGE sunspot of rapid development crossed the central meridian on April 16.1. When photographed at the Royal Observatory, Greenwich, on April 13, at $10 \mathrm{~h}$. U.T., the spot had an area of 150 millionths of the sun's visible hemisphere; twenty-four hours later the spot, which had become of complex structure, had increased to 1,000 millionths. This is the largest spot seen during the past four months. Greenwich also reports a considerable magnetic disturbance recorded at Abinger as having begun suddenly on April 17 at $\mathrm{l}^{\mathrm{h}} 55^{\mathrm{m}}$. There would appear to be a definite association between the big sunspot and the terrestrial magnetic storm.

\section{Announcements}

M. JACQUES DUCLAUX, professor of general biology in the Collège de France, Paris, has been elected a free academician of the Paris Academy of Sciences, in succession to the late M. d'Ocagne.

Dr. Albert Szent-Györgi, professor of medical chemistry at Szeged, Hungary, has been awarded the A. W. Hoffmann Memorial Medal by the German Chemical Society.

Dr. T. Moran, principal scientific officer at the Low Temperature Research Station, Cambridge, has been appointed director of research at the Laboratories at St. Albans of the Research Association of British Flour-Millers, in succession to Dr. E. A. Fisher. Dr. Moran will take up his duties on June 1.

Colonel A. S. Angwrn, deputy engineer-in-chief, has been appointed Engineer-in-Chief of the Post Office, on the retirement of Sir George Lee on May 31.

ON March 29, the Earl of Athlone, as president of the National Hospital for Nervous Diseases, Queen Square, formally accepted the Associated British Cinemas Laboratory for Biochemical Research and the Gaumont-British Laboratory for Histological Research.

A COURSE for those engaged in the training of mental defectives in occupation centres, institutions or mental hospitals and for home teachers has been arranged by the Central Association for Mental Welfare. Further information may be obtained from the Educational Secretary of the Association, 24 Buckingham Palace Road, London, S.W.1.

THE annual meeting of the U.S. National Academy of Sciences is to be held in Washington during April 24-25. The sessions for the presentation of scientific papers are open to the public. In the evening of April 24, the president of the Royal Society, Sir William Bragg, will deliver the second Pilgrim Trust
Lecture, which will be entitled "History in the Archives of the Royal Society".

The Meyer Medal for distinguished services in plant introduction has been awarded by the American Genetic Association to Miss Kate O. Sessions, of San Diego, California. Miss Sessions, who is eighty-two years of age, has contributed greatly to the horticultural beauty of southern California through fifty years of active work spent there as a landscape gardener and horticulturist. The Meyer Medal is awarded periodically by the Council of the American Genetic Association.

A national conference on the "Wider Aspects of Nutrition" will be held under the auspices of the British Medical Association in the B.M.A. House, Tavistock Square, London, W.C.1, during April 27-29. The inaugural address will be delivered by Sir Arthur Salter. The following sessions will be held: (1) Medical Aspects of Nutrition; (2) Means of Stimulating Production, (a) Home Agriculture, (b) Overseas Producers; (3) Means of Stimulating Consumption, (a) Family Allowances, Provision of Cheap or Free Milk or Meals in Necessitous Cases, (b) Education. On April 28, at 8.15, Prof. V. H. Mottram will deliver the Sir Charles Hastings Public Lecture entitled "Nutrition and the Public Health". Admission to the conference is by ticket obtainable from the secretary of the B.M.A.

THE following appointments and promotions in various branches of the Colonial Service have recently been made: T. F. Blood, inspector of produce, Nigeria; F. A. Leeds, inspector of plants and produce, Gold Coast ; I. Sibson, inspector of plants and produce, Gold Coast; R. Johns (agricultural officer, Zanzibar), agricultural officer, Fiji; A. F. Nichols (assistant director of agriculture), director of agriculture, Seychelles; W. M. Robertson (conservator of forests, Sierra Leone), conservator of forests, Tanganyika Territory; F. B. Higgins (senior inspector of mines), chief inspector of mines, Gold Coast ; R. L. Creery (veterinary officer), senior veterinary officer, Kenya; W. G. Emerson (veterinary officer), senior veterinary officer, Kenya; W. Fotheringham (veterinary research officer), senior veterinary research officer, Kenya.

WE have received from Messrs. Griffin and Tatlock, Ltd., Kemble Street, London, W.C.2, a copy of their new 1,150-page Catalogue No. $15 \mathrm{~B}$ of modern chemical apparatus. This has been entirely rewritten in the light of modern laboratory equipment and technique, and comprises a very wide range of apparatus for use in all branches of chemistry. It is planned in thirteen sections, in each of which the items are in alphabetical order, and there is a detailed general index. The apparatus is illustrated and in many cases there are adequate descriptive notes, so that the volume is much more than a mere catalogue of prices. In many cases the theory of the apparatus is briefly yet adequately described. This catalogue would be found of great value in any chemical laboratory. 